\title{
Determinación de sulfuros de hierro en pizarras para cubiertas del noroeste de España
}

\author{
Determination of iron sulphides in roofing slates \\ from the north west of Spain
}

GARCÍA-GLINEA, J." ${ }^{\prime \prime}$ CARIDENES V. " LOMBARIERO, M. ${ }^{m}$, DESILONIZ, M. I. ${ }^{\text {name }}$

${ }^{*}$ Museo Nacional de Ciencias . Vaturales, ${ }^{n * 2}$ Instituto Geológico y Minero de España,

Fecha de recepción: 3-IV-(0)

Dept. Microbiología. Facultad Ciencias Biológicas, UCM

Fecha de aceptación: 30-VII-0I

ESPAÑ

\section{RESUMEN}

Las formaciones ordovícicas del Sinclinal de Truchas concentran la mayor producción mundial de pizarra para cubiertas y el mayor numero de canteras en producción. Las pizarras para cubiertas muchas veces contienen sulfuros de hierro cristalizados en forma de pirita, pirrotina y otros minerales. Bajo condiciones atmosféricas, este tipo de sulfuros se oxida en las superficies y mancha las placas colocadas, tanto más cuanto más inclinado sea el tejado. Los productores de pi-arra distinguen bien entre piritas inofensivas (es decir, (abos de pirita resistentes) y piritas oxidables (es decir, otros minerales metálicos rápidamente oxidables como pirrotina, calcopirita, marcasita y arsenopirita). Se propone una combinación de dos métodos: (a) una rutina de identificacion mas objetiva utilizando proporciones de elementos analizados por microsonda electrónica y (b) una determinación cuantitativa de áreas de sulfuros oxidados en planos de exfoliación (001) de pizarra mediante registro fotográfico digital. Las relaciones obtenidas $F$ e/S de setenta muestras metálicas se representan en un grafico $X Y$ y' se definen bien tres. zonas diferentes: pirita, pirrotina y oxi-hidróxidos de hierro. La determinación cuantitativa de sulfuros de hierro en la placa de pizarra fue llevada a cabo sumergiéndola seis horas horizontalmente en agua oxigenada y después régistrando las oxidaciones con una cámara fotográfica digital y analizando) los resultados con programa comercial de análisis de imagen (SigmaScan 1:.5). El método propuesto es mejor y más rápido que la norma Española UNE vigente (UNE-EN-12326-2), que supone varios ciclos de choques térmicos durante an mes. El inconveniente del uso obligado de una microsonda electrónica podría paliarse instalando una en el Centro Tecnológico de la Pizarra de Sobradelo de Valdeorras (Orense) o utilizando una lupa binocular moderna para reconocer los minerales de hierro.

\section{SUMMARY}

The most important production of roofing slates in the world is quarried from the Ordovician formations of the Truchas Syncline, which have the largest amount of working quarries. Roofing slates, sometimes, have crystallized iron sulphides such as pyrite, pyrrhotite and other minerals. These iron sulphides oridise and stain the tiles when are exposed to atmospheric conditions, so much oxidized how much more inclined is the roof. Galician quarrymen distinguish between harmless pyrite (i.e., resistant cubes of pyrite) and damaging pyrite (i.e., other alterable metallic minerals such as pyrrhotite, chalcopyrite, marcasite and arsenopyirite). An improved identification method is proposed using both methods (a) chemical element ratios of samples under electron microprobes and (b) quantitative determination of the iron sulphides in the slate measuring the oxidi-ed areas by digital camera. The analysed $\mathrm{Fe} / \mathrm{S}$ ratios, in an $X Y$ plot, of seventy metallic samples, define three separated sones: pyrite, pyrrhotite and iron oxi-hydroxides. Quantitative determination of iron sulphides in the slate tile were performed by sinking the tile horizontally for six hours in oxygen peroxide (3\% diluted) and capturing the oxidation areas with a magnetic camera and analysing the bitmap images with Sigma-Scan 5 software. The proposed method is faster than the Spanish UNE norm (UNEEN-12.326-2 Sept.2000), which requires thermal strike cycles for a month. The necessary use of heary analytical equipment such as electron microprobes can be facilitated by installing it in the Slate Technological Centre of Sobradelo de Valdeorras (Orense) or by using a simple optical stereoscopic soom microscope to classify the iron minerals.
PAIABRAS ClaAVE: pirita, pirrotina, pizaltra. oxidación. microsonda electrónica
KEYWORDS: pyrite, prrhotite, slate, oxidation. electron microprobs 


\section{INTRODUCCIÓN}

Las determinaciones de sulfuros de hierro por difracción de rayos $X$ en pizarras para cubiertas resultan muy difíciles por el pequeño tamaño de los cristales que aparecen dispersos por las superficies de las pizarras. La diferenciación entre pirita y pirrotina es crucial debido a su gran diferencia ante la oxidación atmosférica. La pirita tiene una red cristalográfica cúbica bien ordenada y estable, que resiste más la oxidación.

Un requisito importante para la oxidación de los sulfuros es el pH (de 2 a 4), en donde algunas bacterias sulfooxidantes como Thiobacillus ferrooxidans, aceleran el proceso. La oxidación de la pirita (1) ha sido muy estudiada con diferentes objetivos, por ejemplo: (a) en la purificación de masas de pirita-carbón-caolín (2); (b) para conocer el cfecto del oleato sódico y del ácido ascórbico en la inhibición de la oxidación de la pirita (3-4); para protegerla de la oxidación con resinas y barnices (5), etc. Sin embargo, no existen estudios específicos de deterioro de pizarras por oxidación de sulfuros de hierro.

Lo que, además, es un problema muy importante para la industria de la pizarra de techar del noroeste español. Por otra parte, hay que recordar que España es el primer productor de pizarras para cubiertas, aproximadamente cl 87\% de la producción mundial (6-8). En la pasada década, las exportaciones crecieron desde 250 millones de dólares hasta alcanzar los 625 millones de dólares. Muchas de las canteras están localizadas en formaciones del Ordovícico medio-superior del macizo Hercínico peninsular, en el Sinclinal de Truchas, donde están las formaciones geológicas ordovícicas Casaio y Luarca, que son las que tienen mayor número de canteras y de problemas de sulfuros de hierro (Figura 1) (9). Las condiciones paleo-ambientales de formación de estas pizarras no están aún totalmente aclaradas y son objeto de controversia; sin embargo generalmente se admite que los sedimentos arcillosos que dieron origen a la pizarra se formaron en aguas marinas reductoras o con poco oxígeno. La calidad de las pizarras para cubiertas del noroeste español es la mejor del mundo debido a sus extraordinarias propiedades de fisibilidad y homogeneidad, lo que permite exfoliar placas muy finas y de gran formato. Quizás, el peor problema de estas pizarras sea la presencia ocasional de sulfuros de hierro en las superficies de las placas que acaban extendiendo manchas de óxidos de hiero y devaluando el producto lo que está obligando a desarrollar métodos modernos. rápidos y seguros para determinar el contenido de sulfuros de hierro de las pizarras.

La oxidación de los sulfuros de hierro en pizarras depende de los siguientes factores: (a) especic mineralógica, (b) forma de los cristales, (c) condiciones

\section{INTRODUCTION}

X-ray diffraction studies of iron sulphides from roofing slates are difficult due to the small size of the crystals scattered on the surface of the slate. The pyritepyrrhotite separation is crucial given their different behaviour under atmospheric oxidation. Pyrite has a well-ordered cubic lattice that resists better than pyrrhotite, which has a hexagonal structure with a poorer resistance to oxidation.

An important requirement for the oxidation of iron sulphides is pH ranging from 2 to 4, in which, some sulphur-oxidant bacteria, for example Thiobacillus ferrooxidans, accelerates the process. The oxidation of pyrite (1) has been studied extensively for the following purposes: (a) in the heap leaching of pyritic-coalbearing kaolin ore (2); (b) to discover the effect of sodium oleate and ascorbic acid on inhibiting pyrite oxidation (3-4): (c) to protect it using synthetic resins (5), etc. However, there are no specific studies on the deterioration of slates caused by the oxidation of iron sulphide.

This is an important problem for the roofing slate mining industry in the Northwest Spain. Spain is the highest producer of roofing slates, with approximately $87 \%$ of World production (6-8). During the last decade exports have increased from U.S. $\$ 250$ million to U.S. $\$ 625$ million. Most of the slate quarries are located on the middle-upper Ordorician formations of the Hercynian massif of Spain; in the Truchas Syncline, in which are the Ordorician geological formations of Luarca and Casaio. Both have the largest amount of working quarries and the iron sulphide problems (Figure I) (9). The paleo-environment where the slates were formed is uncertain and controversial; however. the earlier argillaceous sediments were certainly formed in anoxic or low-oxygen seawater conditions. Spanish roofing slates are the best of the World thanks to their good fissility and homogeneity, which allows them to be made in very flat, large and light tiles. The major problem is the existence of iron sulphides on the surfaces of the slates, which stain them by oxidation and cause them to lose value. Therefore, it is crucial to develop studies on determination, occurrence and palliatives for these iron sulphides.

The oxidation of iron sulphides in slates is determined by the following variable factors: (a) mineralogical specimen, (b) shape of the crystals. (c) environmental 


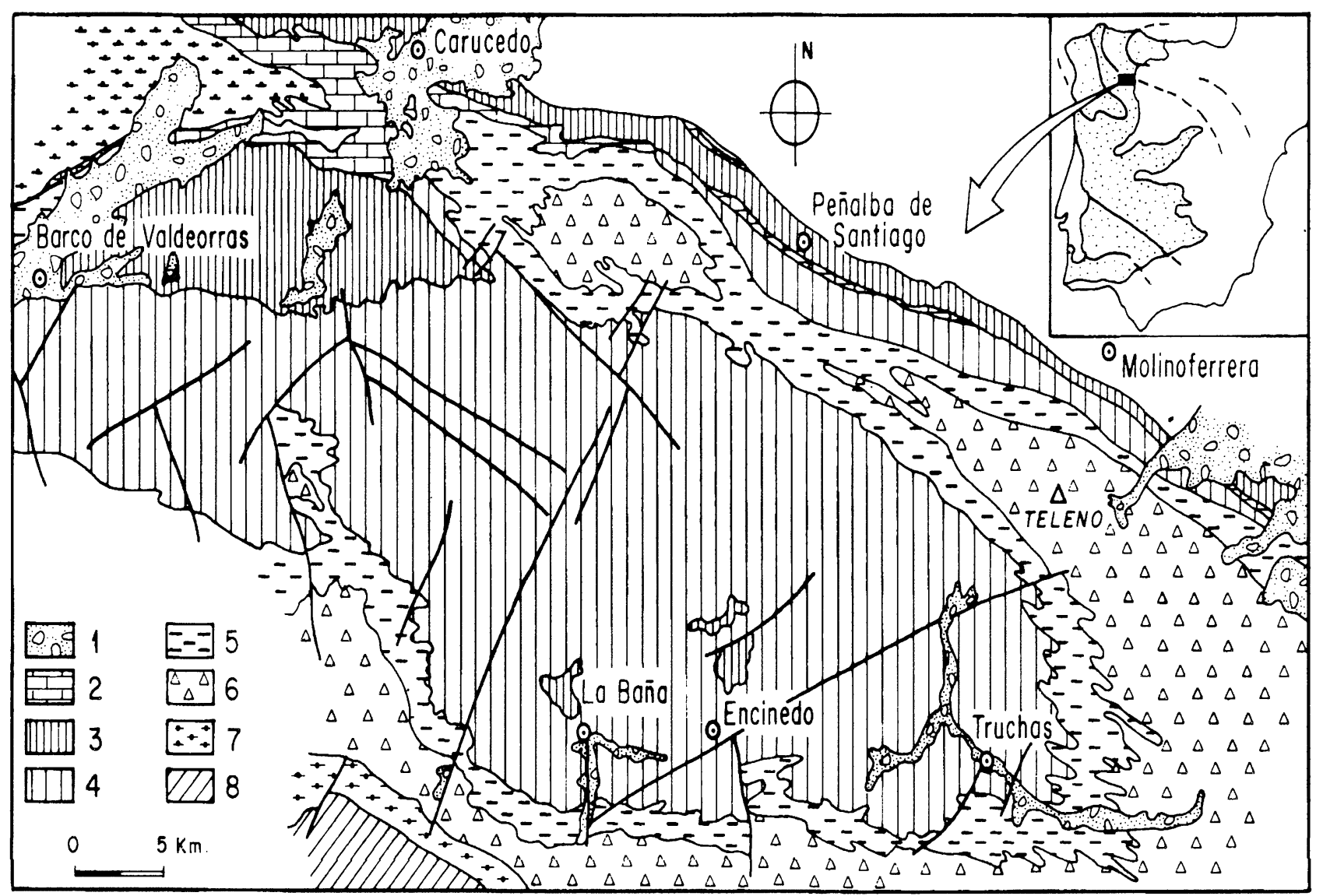

Figura 1.- Mapa geológico del Sinclinal de Truchas (Galicia): 1. Sedimentos terciarios. 2.- Calizas de La Aquiana. 3.- Pizarras silúricas, 4.- Pizarras del Ordovícico superior y medio. 5.- Pizarras de Luarea. 6. Cuarcita armoricana, 7.- Pizarras de Los Montes. 8.- Basamento ígneo.

Figure 1." Geologacal map of Truchas Sincline in Galicia (Spain): 1.- Tertiary sediments. 2. - La Aquiana Limestone. 3.- Silurian shales, 4. Lipper and Middle Ordovicic Slates, 5.- Luarca Slates, 6.- Armorican Quartsite, 7. I.os Montes Slate. 8. Igneous basement.

ambientes, como temperatura, pH, o química del agua. (d) procesos biológicos producidos por Thiobacillus y Leptobacillus ferrooxidans (10-12), (c) contaminación atmosférica, etc. Las causas principales del deterioro de los tejados de pizarra son la oxidabilidad del hierro ferroso de los sulfuros y la necesaria inclinación de los tejados que extiende las manchas. Asumiendo estos procesos naturales, se puede estudiar un amplio abanico de acciones paliativas, de tipo geológico, minero o industrial (biológico o físico-químico), empezando por una metodología de determinación precisa de los sulfuros de hierro que permita prever su futura oxidabilidad encima de los tejados. La presencia de sulfuros de hierro acarrea pérdidas de entre un $30 \%$ y $50 \%$ de los beneficios previstos. La presencia de sulfuros de hierro en bloques de pizarra depende de la cantera y del nivel estratigráfico que se esté explotando, algunos con alto contenido en sulfuros de hierro. La especie mineralógica del sulfuro es muy importante. Los canteros diferencian bien los tipos de sulfuros de hierro: (a) piritas inofensivas, es decir, cubos de pirita que aguantan bien la oxidación y (b) piritas oxidables, conditions such as temperature, pH or water chemistry, (d) biological processes inducted by Thiobacillus and Leptobacillus ferrooxidans (10-12), (e) air pollution, etc. The consistent causes of the architectonic damages in slate roofs are the reduced character of the ferrous iron in sulphides and the necessary inclined position of tiles on roofs. Assuming these natural processes, a wide set of palliatives can be considered from the geological. mining and industrial point of view, starting by a methodology to determinate the content of iron sulphides in slate tiles, and their consequent oxidation on roofis. The economic losses caused by iron sulphides in slates, implies reductions of approx $30 \%-50 \%$ in their final benefits. The presence of iron sulphides in tiles stems from the variable conditions in specific: quarries and stratigraphic beds. The mineralogical specimen of iron sulphide is very important. Galician slate workers recognise harmless pyrites, which are cubes of pyrite mineral with low oxidation, and damaging prites, usually other small-sised iron minerals with different crystallographic arrangementsfor example chalcoprite. marcasite and arsenopyirite. 
es decir, otros minerales con menores tamaños de grano y diferentes estructuras cristalinas como pirrotina. calcopirita, marcasita y arsenopirita que oxidan rápidamente y ensucian las placas de pirita.

El objetivo de este trabajo es proponer una combinación de métodos de análisis de sulfuros de hierro en pizarras de techar, primero analizar la proporción $\mathrm{S} / \mathrm{Fe}$ por análisis químico puntual $\mathrm{y}$, después, determinar cuantitativamente las áreas de sulfuros oxidados en planos de exfoliación $(001)$ de pizarra mediante registro fotográfico digital.

\section{METODOLOGÍA}

Las observaciones ópticas de los sulfuros de hicro sobre las pizarras de techar fueron realizadas con un video microscopio Olympus que incluye: (a) fibras ópticas y fuente halógena, (b) Cabezas de iluminaciónTV con lentes, (d) Unidad de Control $A G C$ con shutter Knobs, etc. Y (e) accesorios VCR, videoprinter, video escala y adaptadores. Los análisis petrográficos se hicieron con láminas delgado-pulidas, de hasta 35 micrómetros de espesor, en un microscopio de polarización, objetivo de 10()$\times$ con una cámara fotográfica magnética del Departamento de Geología del Museo Nacional de Ciencias Naturales, los ficheros gráficos en memorias compactflash fueron llevados a un Pentium-III-850 para ser analizados con un programa de análisis de imagen Sigmascan Pro v.5 de SPSS que permite identificar tonos de grises, matices. formas, etc. Sin embargo, la identificación pudo ser mejorada enormemente bajo la microsonda electrónica (JEOL Superprobe JXA-89()0M) del Centro de Microscopía Luis Bru de la Universidad Complutense de Madrid, calculando las relaciones de contenidos químicos $\mathrm{Fe} / \mathrm{S}$ de los sulfuros de hicro y sus fórmulas mineralógicas (pirita $\mathrm{FeS}_{2}$, pirrotina $\mathrm{Fe}_{1}, \mathrm{~S}$ ). En cl caso de la pirita el S es $53 \%$ y el Fe $47 \%$, sin embargo en la pirrotina el S va desde $74 \%$ hasta $42 \%$ y el Fe desde el $58 \%$ al $26 \%$, la pirrotina tiene mayores contenidos de Fe que de $\mathrm{S}$. Este trabajo experimental permite diferenciar pirita y pirrotina con poco crror. Además, se realizaron algunas observaciones de cristales de sulfuros de hierro bajo el microscopio electrónico de barrido (SEM), previamente, las muestras fueron metalizadas con oro $(20 \mathrm{~nm})$. Estos estudios de SEM fueron realizados en un Philips XI_20 SEM a 20-30 kV. Los análisis de energías dispersivas (EDX) fueron obtenidos con un Philips EDAX PV99()() con un detector de luz de tipo ECON.
The largest World production of roofing slates is quarried from the Ordovician formations of the Truchas syncline. where the geological formations of Luarca and Casaio have the largest amount of quarries hut also iron sulphide contents. (Figure l): This is a good reason to develop fast. modern and secure methods to determine the iron sulphide content in roofing slate.

The aim of this note is to propose wo evaluation methods on the oxidization of a roofing slate: (a) determination of $\mathrm{Fe} / \mathrm{S}$ ratios under electron microprobes and (b) quantitative determination of the iron sulphides in the slate $(001)$ exfoliation planes measuring the preoxidized areas with $H, O$, by digital camera.

\section{METHODOLOGY}

The optical observations of the iron sulphides on the roofing slates were performed using an Olympus Video Microscope which includes: (a) light guides and halogen bulb, (b) TV-Illumination heads plus lenses (from 20x to) 100(x), (c) TV-Monitor; (d) Control unit with light controls, $A G C$ and Shutter Knobs, etc: and (e) Accessories such as VCR, video printer, video scale and mounting adapter: The petrographic optical analyses of small sample chips, cut-polished (up to 35 micrometers in thickness), were carried out using a polarizing microscope with a Photo-Camera of the Department of Geology of the Museo Nacional Ciencias Naturales (Nikon Coolpix 950), the *.jpg image-files were recorded in a memory unit Compactflash USB of I6MB to be carried out to a ScanDisk disc reader of a $P C$ compatible to be analysed with software SigmaScan Pro 1:5 of SPSS which allows the classification of different grey colour hues, shapes, etc. These optical methods allow accurate separation of pyrite and pyrrhotite phases. Howerer, the identification can be improved by using the electron microprobe (Jeol Superprobe JXA$8900 \mathrm{M})$ of the Centro de Microscopia Luis Bru of the University Complutense of Madrid and calculating the chemical element ratios of the sample. The analysed Fel S ratios of the mineral phases allow the analysis of their mineralogical formulae (pyrite $\mathrm{FeS}$, and pyrrhotite $\mathrm{Fe}$. S). In the case of pyrite, $S$ is $53 \%$ and $F e$ is $47 \%$ and in that of pyrrhotite, Sranges from $74 \%$ to $42 \%$ and $F e$ ranges from $58 \%$ to $26 \%$, pyrrhotite has a large content of Fe rather than S. This experimental data permits the error free separation of pyrite-pyrhotite. For additional Scanning Electron Microscopy (SEM) studies, iron sulphide (rovtals were coated with gold $(20 \mathrm{~nm})$ in a sputter coating unit. The SEM observations were carried out in a Philips XI.20 SEM at aceelerating voltages of 20-30)kV Energy dispersive $X$-ray microanalyses (EDX) "ere obtained using a Phillips EDAX 


\section{RESULTADOS}

Setenta muestras de sulfuros de hierro fueron seleccionadas de testigos de sondeos realizados a través de la secuencia estratigráfical y a partir de placas comerciales procedentes de niveles estratigráficos y canteras conocidos descritas en el mapa geológico regional y en la columna estratigráfica de muestreo (Figura 2). También se observaron los sulfuros de hierro por otras técnicas complementarias como XRD. microscopía óptica de reflexión y SEM-FDAX (Fig̣ara 3). Los elementos seleccionados para el análisis fueron As. Pb. Fe, S. Se, Sb, Ab. Bi, Zn. Co, Nd. Ce. Ni. Cu y Te. Los porcentajes de hierro y azufre, recalculados a 100\% se representan en la Figura 4: muestran tres zonas bien diferenciadas: (1) \%ona de la pirita. Las proporciones de hierro nunca llegan al $50 \%$, sin embargo. el azufre está próximo al $60 \%$. Estos resultados concuerdan con las proporciones relativas de la fórmula de la pirita. (2) Zona de la pirrotina. El contenido de hierro es mas elevado, por encima del $60 \%$ y el eontenido de azufre mas bajo. (3) Zona de los óxidos de hierro. Estas muestras no muestran azufre, o tienen muy poca cantidad de azufre, y el contenido de hierro es muy elevado. Observando la agrupación de resultados del diagrama podemos ver que las zonas de la pirita y pirrotina están próximas una de otra

\section{DISCUSION Y CONCILUSIONES}

El sistema utilizado para medir la oxidación futura de sulfuros de hierro sobre tejados de pizarra se realiza actualmente por ensayos de ciclos térmicos siguiendo la norma Espanola y Europea UNE (UNE-EN-12.326-2 Sept.2()() Dep.Legal M36389:20(0)). El ensayo está compuesto de 20 ciclos de 24 horas cada uno, lo que suma 20 días a los que hay que anadir otros ocho días en fines de semana, en total suman 28 días para prevenir la futura oxidación de una partida de placas de pizarra. El ensayo se lleva a cabo en una estufa convencional que admite de 9 a 11 placas.

Utilizando microsonda electrónica es posible analizar de 75 a 90 placas por día. más medio día de preparación de muestras con resinas epoxy y pulido con óxidos de alumina (Tabla 1). Antes de someter las muestras a la microsonda electrónica es necesario metalizarlas con grafito en vacío en una metalizadora de arco eléctrico. Bl equipo utilizado (Univ. Complutense Madrid) permite meter en la cámara de vacío cuatro probetas con 49 muestras cada una (7 filas $x 7$ columnas), lo que suma un total de 196 muestras en un mismo ciclo de vacio y con una misma rutina analítica.

Para realizar una determinación cuantitativa de la proporción de sulfuros de hierro oxidables en la pizarra. se propone sumergir seis horas en agua oxigenada al 34 ;

\section{RESULTS}

Serenty samples of iron sulphides were taken from the drill core across the stratigraphic section and from commercial tiles where the stratigraphic level of the quarries was known (Figure 2). The iron sulphides of samples were studied using different techniques, such US microscopy of reflection optics, XRD and SEMEDAX (Figure 3). The elements analyed were As, Ph. $\mathrm{Fe}_{\mathrm{e}} \mathrm{S}, \mathrm{Se}, \mathrm{Sh}, \mathrm{Ag}, \mathrm{Bi}, \mathrm{Zn}, \mathrm{Co}, \mathrm{Nd}, \mathrm{Ce}, \mathrm{Ni}, \mathrm{Cu}$ and $\mathrm{Te}$. The iron and sulphur percentages were recalculated up 10) 100\% and represented in the Figure 4, showing three clear areas, as follows: (1) Pyrite sone. The iron proportions do not reach up the $50 \%$, meanuhile the sulphur is close to 60) \%. This result agrees with the ratio for the prite formula. (2) Pyrrhotite sone. The iron content is higher: orer the $60 \%$, the content of sulphur is lower and (3) Iron oxides sone. The iron ovide samples studied did not display sulphur or had very low amounts of sulphur and the iron contents were lery high. The sulphur and iron contents of samples from pyrite and prrathotite ones are close together in the $X Y$ plot.

\section{DISCUSSION AND CONCLUSIONS}

The system used to measure the future oxidation of iron sulphides in roofing slates is thermal strike tests described in the Spanish UNE norm (UNE-EN-12.326-2 Sept.2000 Inep.Legal M.36389:2000). The test (omprises of 20 aveles of 24 hours each. which is 20 working days plus cight days at weekends. This gives us a total of 28 days to forecast the future oxidation of the batch of tiles. The method uses a conventional oven. which holds between 9 to $1 /$ tiles.

Using an electron microprobe, it is possible to analyse between 7.51090 tiles a day half a day is required to prepare the samples in epory resins and polish them with alumina powders (Tabla l). The equipment (Unis: Complutense Madrid) uses four square resin containers which can hold 49 samples (7 files \& 7 columns) each, giving us a total of 196 samples in the same sacum and analytical routine'.

A quantitative determination of the amount of iron sulphides in the tile can be performed sinking the tile in orgen perovide $1.3 \%$ diluted) horizontally for six 


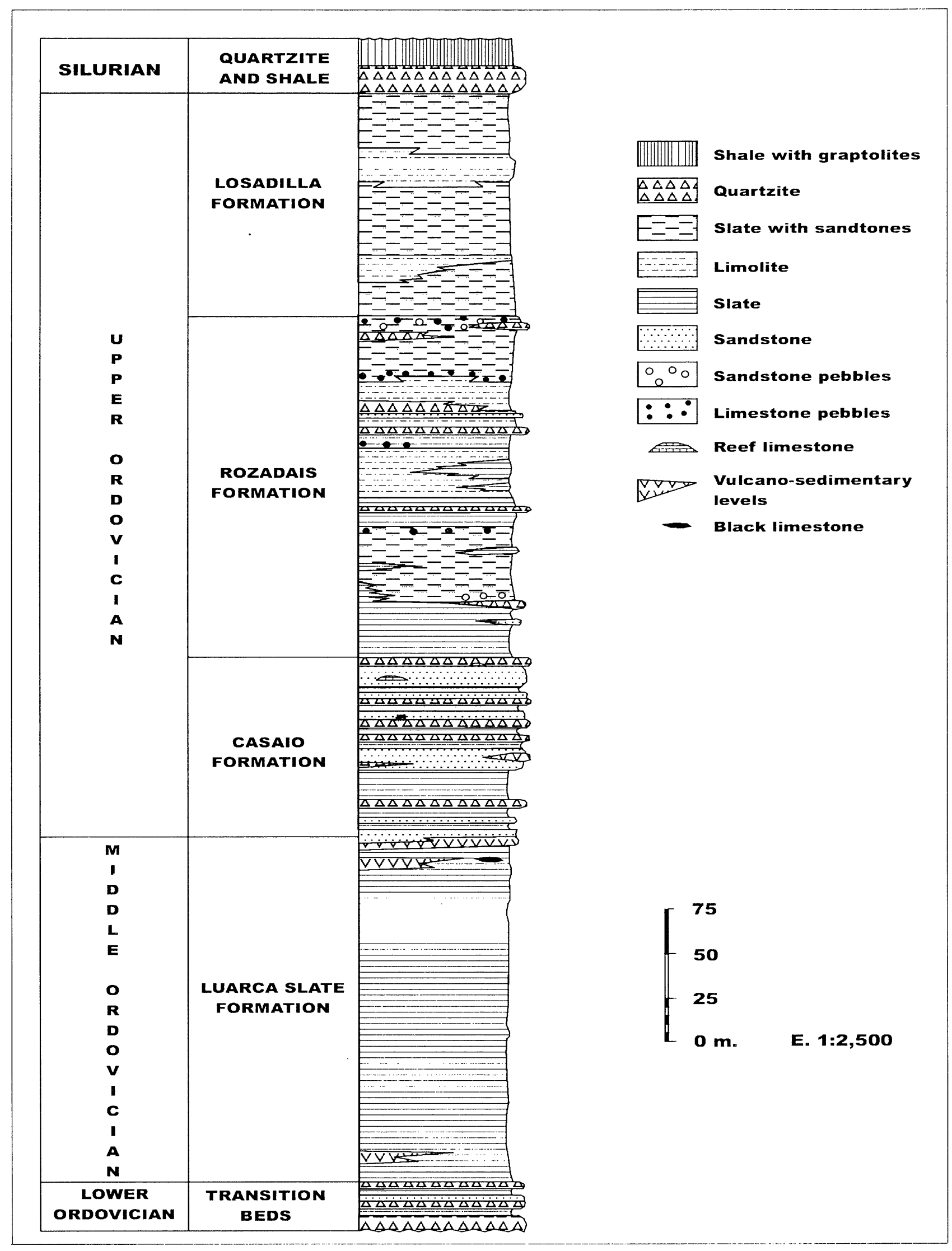

Figura 2. Columna estratigráfica del flaneo sur del Sinclinal de Truchas donde se efectuaron los sondeos a se tomaron las muestrass de sulfuros de hierro.

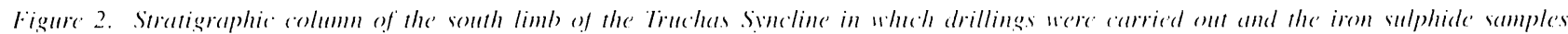
collecicid. 

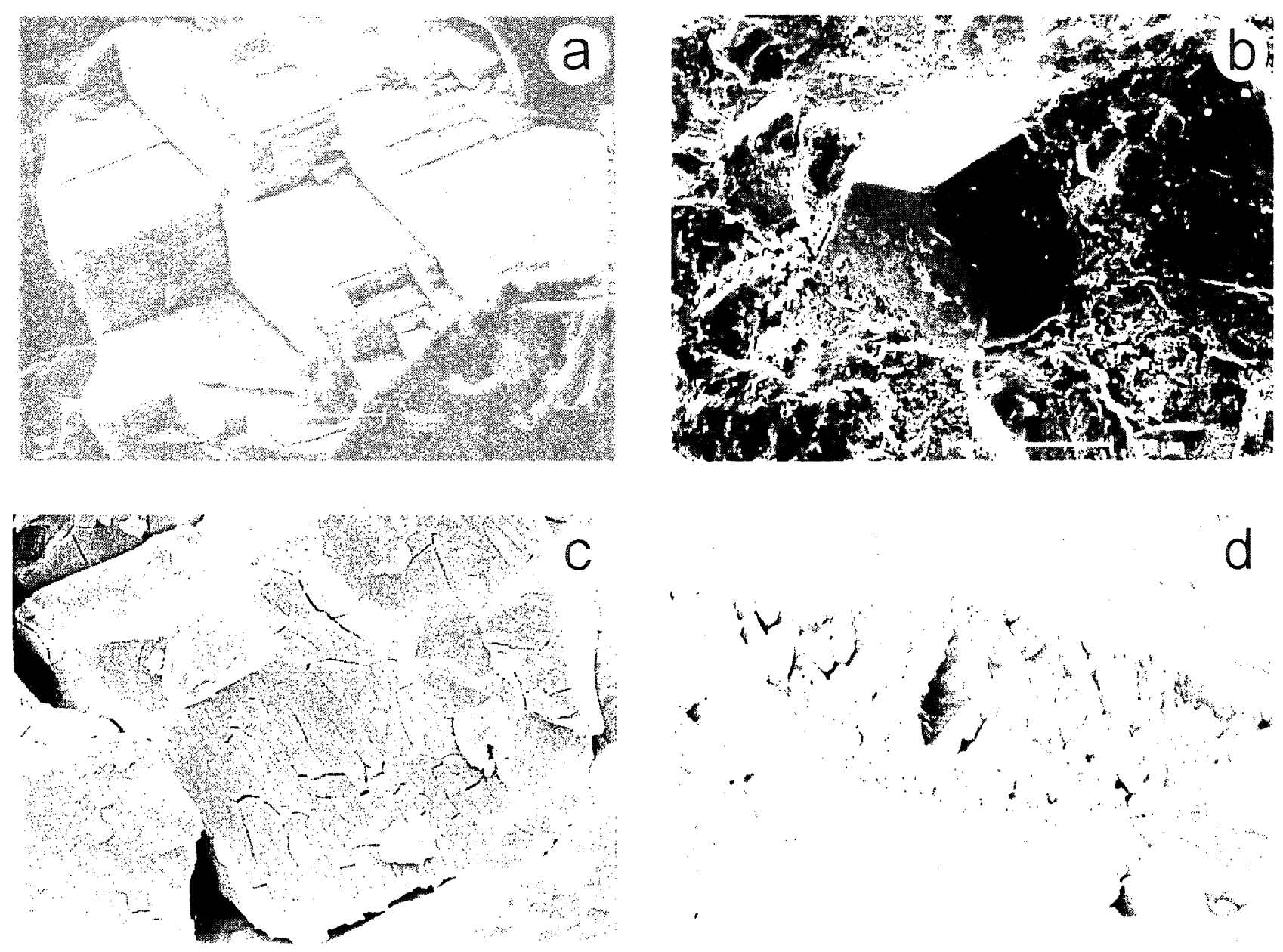

Figura 3. Imagenes de microscopia electrónica de barrido de sulfuros de hierro en pizaras: (a) escalones de crecimiento de un cristal eúbico de pirita. (b) Pentágono-dodecaedro de pirita en pizarra. también sin alterar. (c) Alteraciones naturales sobre una cara de un eristal de pirrotina. (d) detalle de los pozos de corrosión natural sobre la pirrotina.

Figure 3.- Scanning electron microscops images of iron sulphides on slates: (a) groning steps of a cubic arytal of pyrite. (b) Pentagonaldodecahedron of prete on slate also without alteration. (c) Vatural alteration on a cristal face of prrrhotite. (d) Detail of the corrosion pits in prohotite.

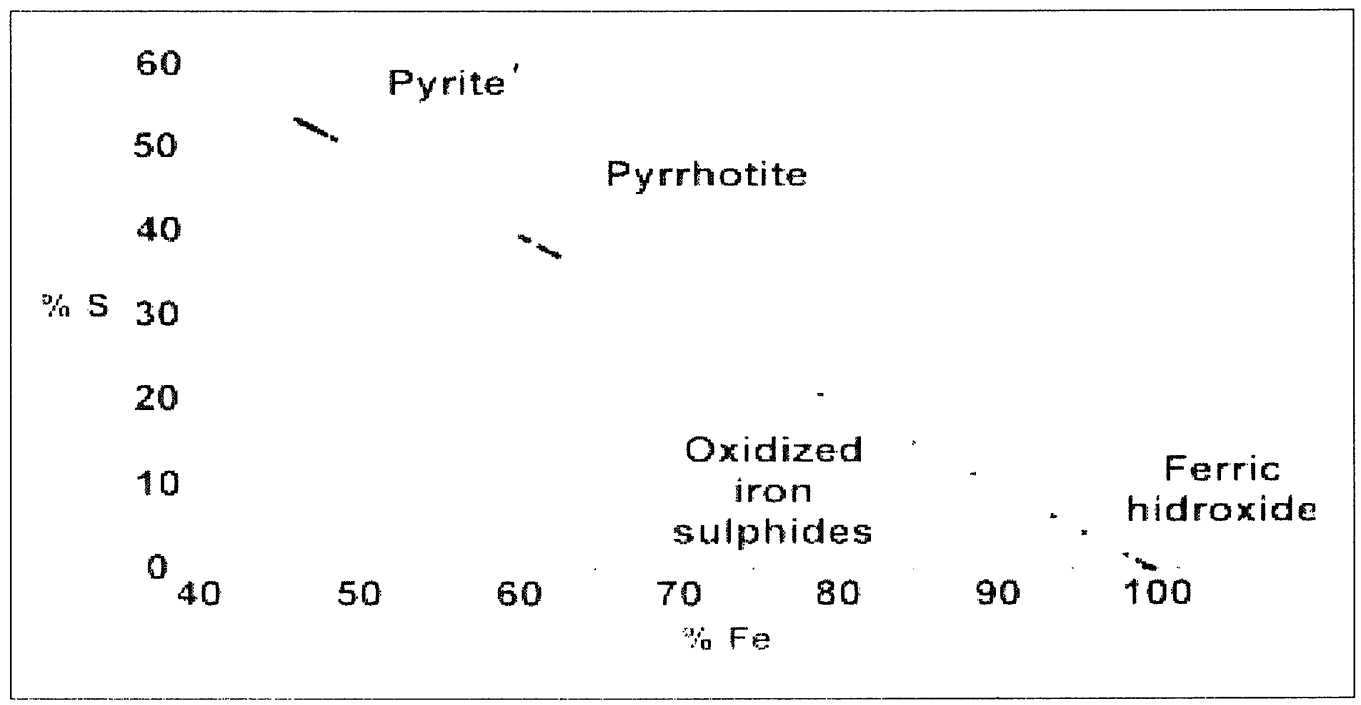

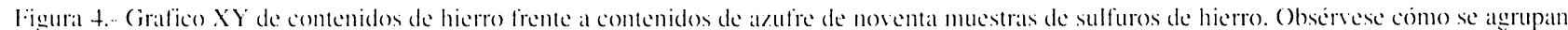
ent tres anas diferentes: pirita. pirrotina y ixides de hierro.

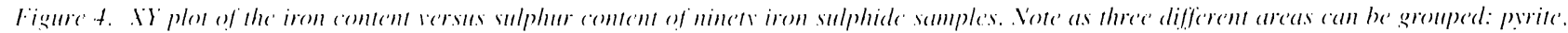
prorhenite and iron ovides 
TABLA I:TABIEI

Análisis químicos por microsonda electrónica de sulfuros de hierro de pizarras de techar (datos del gráfïco XY) (Chemical cinalyses by electron-microprobe of iron sulphides firom roofing slates ldata in XY plot))

\begin{tabular}{|c|c|c|c|c|c|c|c|c|}
\hline $\begin{array}{c}\% F e \\
\text { en } \\
\text { muestra }\end{array}$ & $\begin{array}{c}\% S \\
\text { en } \\
\text { muestra }\end{array}$ & $\begin{array}{c}\% \mathrm{Fe} \\
\text { referido } \\
\text { al } 100 \%\end{array}$ & $\begin{array}{c}\% S \\
\text { referido } \\
\text { al } 100 \%\end{array}$ & & $\begin{array}{c}\% \mathrm{Fe} \\
\text { en } \\
\text { muestra }\end{array}$ & $\begin{array}{c}\% \bar{S} \\
\text { en } \\
\text { muestra }\end{array}$ & $\begin{array}{c}\% \mathrm{Fe} \\
\text { referido } \\
\text { al } 100 \%\end{array}$ & $\begin{array}{l}\% \mathrm{~S} \\
\text { referido } \\
\text { al } 100 \%\end{array}$ \\
\hline 0,95 & 0,01 & 99,47 & 0,53 & & 59,11 & 38,57 & 60,51 & 39,49 \\
\hline 46,64 & 50,53 & $47, \overline{99}$ & 51,99 & & 43,77 & 48,49 & 47,44 & 52,56 \\
\hline 46,21 & 50,99 & 47,54 & 52,46 & & $46, \overline{76}$ & $\overline{52,43}$ & 47,14 & 52,86 \\
\hline 58,66 & 38,04 & 60,66 & 39,34 & & 46,63 & 53,11 & $\overline{4} \overline{6}, \overline{75}$ & 53,24 \\
\hline 58,48 & 38,22 & 60,47 & 39,52 & & 55,70 & 9,84 & 84,96 & 15,01 \\
\hline $46, \overline{00}$ & 51,76 & 47,06 & 52,94 & & 12,57 & 0,57 & 95,66 & 4,31 \\
\hline 45,85 & 51,96 & 46,87 & 53,12 & & 59,07 & 38,43 & 60,58 & 39,41 \\
\hline 46,00 & 53,06 & 46,43 & 53,57 & & 45,71 & 11,99 & 79,14 & 20,75 \\
\hline 0,08 & 0,01 & 93,75 & 6,25 & & 46,10 & 51,02 & 47,47 & 52,53 \\
\hline 0,24 & 0,00 & 98,33 & 1,67 & & 59,07 & 38,53 & 60,53 & 39,47 \\
\hline 46,35 & 52,22 & 47,02 & 52,98 & & 59,28 & 38,45 & 60,65 & 39,35 \\
\hline 38,94 & 42,64 & 47,73 & 52,27 & & 58,66 & 38,15 & 60,59 & 39,40 \\
\hline 43,33 & 48,09 & 47,39 & 52,61 & & 58,43 & 37,97 & 60,61 & 39,39 \\
\hline 43,85 & 49,73 & 46,72 & 52,98 & & 56,02 & $\overline{7, \overline{12}}$ & $88, \overline{70}$ & 11,27 \\
\hline 45,92 & 52,35 & 46,73 & 53,27 & & 58,61 & 37,99 & 60,66 & 39,32 \\
\hline 45,47 & 50,24 & 47,51 & 52,49 & & $\overline{0,41}$ & 0,00 & 99,03 & 0,97 \\
\hline 45,99 & 52,06 & 46,91 & 53,09 & & 46,68 & 51,46 & 47,57 & 52,43 \\
\hline 44,88 & 50,44 & 47,08 & 52,92 & & 46,09 & 51,75 & 47,10 & 52,88 \\
\hline 58,69 & 66,10 & 47,03 & 52,97 & & 62,49 & 38,21 & 62,05 & 37,95 \\
\hline 78,26 & 50,16 & 60,94 & 39,06 & & 37,36 & 0,00 & 99,99 & 0,01 \\
\hline 64,10 & 71,27 & 47,35 & 52,65 & & $63, \overline{33}$ & 37,60 & 62,75 & 37,25 \\
\hline 64,18 & 73,37 & 46,66 & 53,34 & & 63,02 & 37,91 & 62,44 & 37,56 \\
\hline 87,36 & 56,64 & 60,66 & 39,34 & & 62,49 & 37,30 & 62,62 & 37,38 \\
\hline 82,96 & 53,90 & 60,61 & 39,39 & & 47,83 & 51,72 & 48,05 & 51,95 \\
\hline 58,87 & 38,09 & 60,72 & 39,28 & & 49,08 & 51,69 & 48,71 & 51,29 \\
\hline 46,46 & 51,42 & 47,46 & 52,52 & & 48,89 & 51,48 & $48, \overline{71}$ & 51,29 \\
\hline 46,13 & 52,09 & 46,96 & 53,03 & & 62,44 & 38,39 & 61,92 & 38,08 \\
\hline 58,68 & 38,09 & 60,64 & 39,36 & & 62,61 & 38,81 & 61,73 & 38,27 \\
\hline 58,82 & 38,06 & 60,71 & 39,28 & & 62,21 & 38,37 & 61,85 & 38,15 \\
\hline 58,63 & $\overline{38,33}$ & 60,47 & 39,53 & & 48,88 & 51,20 & 48,84 & 51,16 \\
\hline 58,45 & 38,14 & 60,51 & 39,49 & & 48,99 & 51,57 & 48,72 & 51,28 \\
\hline 11,59 & 0,00 & 99,80 & 0,00 & & 49,03 & 52,64 & 48,23 & 51,77 \\
\hline 0,38 & 0,00 & 99,48 & 0,52 & & 62,22 & 38,65 & 61,68 & 38,32 \\
\hline 2,22 & 0,00 & 99,51 & 0,18 & & 61,80 & 38,50 & 61,62 & 38,38 \\
\hline 59,09 & 38,56 & 60,51 & 39,49 & & 62,10 & 38,09 & 61,98 & 38,02 \\
\hline
\end{tabular}

las placas en posición horizontal, para provocar una oxidación acelerada, que las mancha de óxidos de hiero y permite diferenciarlos mejor: Además, esta operación no produce extensión del oxido de hierro que mancha la placa y oculta otros centros de oxidación. impidiendo su evaluación. Este método permite determinar la proporción de sulfuros de hierro en pizarra. automáticamente. por análisis de imagen. len nuestros experimentos, se seleccionaron mas de 2()() ventanas sobre superficies de pizarra con sulfuros y fueron digitalizadas fotográficamente con la camara magnétical. hours. This produces an accelerated oxidation, which stains the iron sulphides allowing their observation. This operation does not produce extended staining, by gliding. which masks iron sulphides and stains the host rock. meaning their ratio cannot be evaluated. Using this improsed method, the amount of iron sulphides in slate can alson be determined antomatically by image analises. In our experiments more than 20) windons were selected on the surface of the slate to be captured with the magnetic photographic camera. Using the' 
Utilizando esta rutina propuesta, la evaluación de los tipos de sulfuros de hierro, por microanálisis, y su abundancia en las placas de pizarra, por tratamiento de imágenes, es mejor y más rápido que según el método de la norma Española UNE, por este motivo, se recomienda su uso en los distritos mineros de pizarra. Quizás, el único inconveniente que presenta sea la necesaria utilización de equipos analíticos pesados, tales como la propia microsonda electrónica. Sin embargo, la agrupación de canteras y empresas productoras en las comarcas cercanas de Valdeorras (Orense) y La Cabrera (León) permitiría instalar el equipo, por ejemplo en el Centro Tecnológico de la Pizarra de Sobradelo de Valdeorras (Orense), que prestaría servicio a todas las empresas de la zona. Por otra parte, se podría instalar una versión más ligera del sistema utilizando una moderna lupa binocular SMZ150) Nikon acoplada a un PC y un geólogo experto en mineralogía de visu de estos minerales de hierro.

\section{AGRADECIMIENTOS}

Agradecemos a la empresa Pizarrera gallega SAMACA por el acceso a sus instalaciones y los técnicos de SAMACA, José Carlos Barros, José Eladio Álvarez, Miguel López Delgado y José Manuel de Pedro Delgado por sus comentarios y enseñanzas prácticas sobre la pizarra. Los proyectos DGICYT PB98-0501 y el europeo PNICYDT 1FD97-0959-C03-01 financiaron los trabajos. A Paul Giblin la revisión crítica del manuscrito y a Rafacl González Martín por los estudios de DRX. proposed routine, the evaluation of the iron sulphide types by micro-analysis, and their ratio in slate tiles, by image analysis, is faster and more efficient than using the Spanish UNE norm, for this reason, we recommend its use in slate mining districts. Perhaps, the only inconvenience is the use of heary analytical equipment such as the electron microprobe. However the congregation of slate production and the iron sulphide problem in the Valdeorras (Orense) area, would allow. the possible installation of the electron microprobe, for instance, in the Slate Technological Centre of Sobradelo de Valdeorras (Orense). Additionally, an inexpensive version of this method could be implemented using a modern stereoscopic soom microscope SMZ1500 Nikon and a PC computer, in the hands of an experienced geologist who could recognize these iron minerals.

\section{ACKNOWLEDGEMENTS}

We are grateful to Paul Giblin for the critical review of the manuscript, Rafael Gonsales for the XRD recordings and SAMACA Cooperative for the industrial facilities. The Spanish DGICYT PB98-0501 and European PNICYDT IFD97-0959-C03-01 projects supported the work.

\section{BIBLIOGRAFÍA}

(1) K. Blight, D. E. Ralph, S. Thurgate: Pyrite surfaces after bio-leaching: a mechanism for bio-oxidation. Hydrometallurgy Vol. 58 , n" $3(2000)$, pp. 227-237.

(2) S. M. Lei. W. Q. Gong, C. X. Yuan: Application of microbial oxidation of pyrite.Journal of Wuhan University of TechnologyMaterials Science Edition, Vol, 15. n" I (200()), pp. 49-53.

(3) C. L. Jiang, X. H. Wang. B. K. Parekh: Effect of sodium oleate on inhibiting pyrite oxidation. International Journal of Mineral Processing, Vol. 58, n" (1-4), (2000). pp. 3()5-318.

(4) I. Stubert. S. Peiffer: Inhibition of the oxidation rate of pyrite at neutral pH in the presence of ascorbic acid. Abstracts of Papers of The American Chemical Society. Vol. 213. (1997). p.13.

(5) P. Costagliola, C. Cipriani, C. M. Delfa: Pyrite oxidation: Protection using synthetic resins. European Journal of Mineralogy, Vol. 9, n"1 (1997), pp. 167-174.

(6) J. Garcia Guinea J.. M. Lombardero, B. Roberts, J. Taboada. 1997. Spanish roofing slate deposits. Transactions of the Institution of Mining and Metallurgy. Vol. 106. pp. 205-214.

(7) J. Garcia Guinea. M. Lombardero.. B. Roberts. A. Peto: Mineralogy and microstructure of roofing slate: thermo-optical behaviour and fissility. Materiales de Construcción. Vol. 48, n"251 (1998). pp. 37-48.

(8) J. García Guinea, V. Cardenes, V. Correcher. A. Delgado, M. Lombardero. J. C. Barros: Dehydroxylaton and Ostwald ripening effects in roofing slates. Boletín de la Sociedad Española de Ceramica y Vidrio. Vol.. 39 n" 3 (20)(0)). pp. 85-90).

(9) J. C. Barros: Nuévos datos geológicos y' cartográficos sobre el flanco Sur del Sinclinorio de Truchas (Ourense-Léón. NW de España). Cuaderno Lab. Xeológico de Laxe. Vol. 14 (1989). pp. 9.3-116.

(10) K. Sasaki: Raman study of the microbially mediated dissolution of pyrite by Thiohacillus ferrooxidans. The Canadian Mineralogist. Vol. 35.(1997). pp. 999-1008.

(11) A. Schippers. P. G. Jozsa, Sanz. W: Sulphur chemistry in bacterial leaching of prrite. Applied and Environmental Microbiology. Vol. 62. n"9.(1996). pp. 3424-3431.

(12) P. Bacelar-Nicolau. J. Barrie: Leaching of pyrite by acidophilic heterotrophic iron-ovidising bacteria in pure and mixed cultures. American Society for Microhiology. Vol. 62, n" 2.(1999)). pp. 585-590. 